\title{
人エリーフの耐波安定性に及ぼす開口部の効果について \\ Influence of a gap spacing between arrayed submerged-breakwaters on the stability of armor blocks against waves
}

中村孝幸* ·家田貴之 ${ }^{* *} \cdot$ 大塚明人*** . 小野塚孝 ${ }^{* * *}$ Takayuki Nakamura, Takayuki Ieda, Akito Ohtsuka and Takashi Onozuka

Stability of armor blocks on an array of submerged breakwaters against waves was examined experimentally. Especially, comparing this 3-D experimental results with the conventional 2-D results in a vertical plane, influence of a gap spacing between the breakwaters on the stability of armor blocks has been discussed extensively. It was found out that the gap spacing is important for describing the stability of armor blocks on the submerged breakwater against waves.

Key words : Submerged breakwater, stability, gap spacing, 3-D effects

\section{1.まえがき}

人エリーフは、一般に捨石で構築され、主に入射してくる波をリーフ天端上で強制砕波させることにより透過 波を減勢している。この際、捨石には、強い波力が作用することから、捨石マウンドを保護するためマウンド上 に被覆材を設けるのが通例になっている。従来、このような被覆材や捨石の所用重量の算定には、一般にハドソ ン式 ${ }^{1)}$ やブレブナー・ドネリーの式 $\left.{ }^{2}\right)$ などが用いられている。しかしハドソン式は、人エリーフのように構 成部材が水面下にある場合、法面上では所用重量を過大評価し、天端上では過小評価するなど、その適用吽に問 題がある。このため、建設省土木研究所を中心にして、一連の研究 $\left.{ }^{3}\right) ， 4$ ) が行われ、所用重量の算定式など が提案されている。また、水谷ら $\left.{ }^{5}\right)$ や中村ら $\left.{ }^{6}\right)$ は、人エリーフ上の被覆材に作用する波力を実験的に把握し、 作用波力の水理学的な特性と被覆材の移動特性の関係などを検討している。

しかしながら、これらの研究は、いずれ も鉛直面内における断面 2 次元的な模型実 験や理論解析により検討されてきており、 現地で害際に用いられる3 次元的なリーフ に対する研究は十分に行われていない。事 実、建設省の一連の研究成果に基づき作成 された人エリーフの設計の手引き $\left.{ }^{7}\right)$ の中 でも、被覆材の耐波安定性に及ぼす 3 次元 性の影響については明確でないことから、 断面 2 次元的な検討に基づく結果がそのま ま適用できるものとしている。

本研究では、現地で見られるような一定 の開口幅を設けて空間的に配列された多列 式の人エリーフを対象にして、特に開口部 の有無によるリーフ上の被㠅材の移動特性 の相違を実験的に明らかにしようとするも のである。このとき、被覆材としては、一 般によく利用される偏平な被覆ブロックを 採用した。また、3 次元的な人エリーフで 特有な開口部の影響に着目して、リーフ上

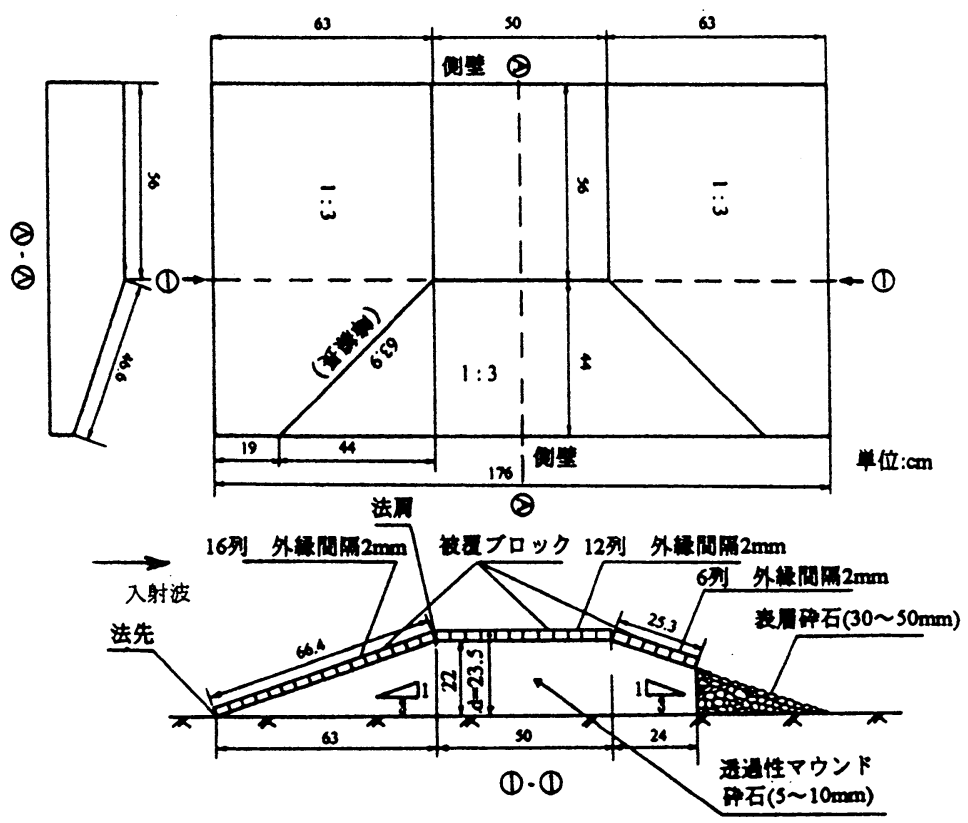

図-1 3 次元人エリーフの模型 の波高分布についても付随的に検討を行い、被覆材の移動特性との関係などについても考察する。

\section{2. 実験装置および実験方法}

\section{1 実験水槽}

本実験に用いた水槽は、愛媛大学工学部の長さ $28 \mathrm{~m} 、$ 幅 $1 \mathrm{~m} 、$ 高さ $1.25 \mathrm{~m}$ の 2 次元造波水槽である。水槽の一端に は造波装置が、他端には砕石からなる1/5勾配の消波工が設けてある。水槽内には、高さ $41 \mathrm{~cm}$ 水平床が設置し てあり、その水平床上に後述する人エリーフの模型を構築した。

\footnotetext{
* 正会員 愛媛大学工学部土木海洋工学科 (790 松山市文京町 3$)$

** 正会員 立興建設株式会社

*** 正会員 三柱ブロック株式会社
} 
2. 2 人エリーフの模型

a) 3 次元模型 : この模型の断面形状は、図一 1 に示すように、水槽の長 軸方向のみならず幅方向にも変化しており、いわゆる平面配置された 3 次 元的な人エリーフが想定してある。これは、水槽側壁が流体力学的な鏡と 仮定できることから、上記の模型堤体まわりの波動場は、鏡像原理により、 ちょうど水槽幅の 2 倍の距離 (2m) を配列ピッチ長とする規則的配列され た人エリーフまわりの波動場を近似していることになる。模型の概要は、 図中に示すように、砕石で構成される台形マウンド上にコンクリート製の 模型被覆ブロックを格子状に規則配列したものである。このとき、隣接す るブロックの外緑間隔 $\mathrm{e}$ は、 $2 \mathrm{~mm}$ 程度とした。使用した被覆ブロックは、三 柱ブロック社製のメガロックで、図ー 2 に示す寸法の扁平な形状のもので ある。そして、上記したような鏡 像原理による模型化が妥当とする と、ここでの模型人エリーフは、 開口率（隣接するリーフ問の開口 幅と配列ビッチ長との割合で定 義）が44\%に相当する。なお、この 実験で想定した模型の縮尺は、約 1/50程度である。

b) 断面 2 次元模型 : 本研究では、 断面 2 次元的な人エリーフと上記 のような 3 次元的な人エリーフに よる結果との比較を行っている。 このとき,比較対象にした 2 次元模 型を図一 3 に示す。この 2 次元模 型では、上記の 3 次元模型に比較 して、波向き方向のリーフの天端
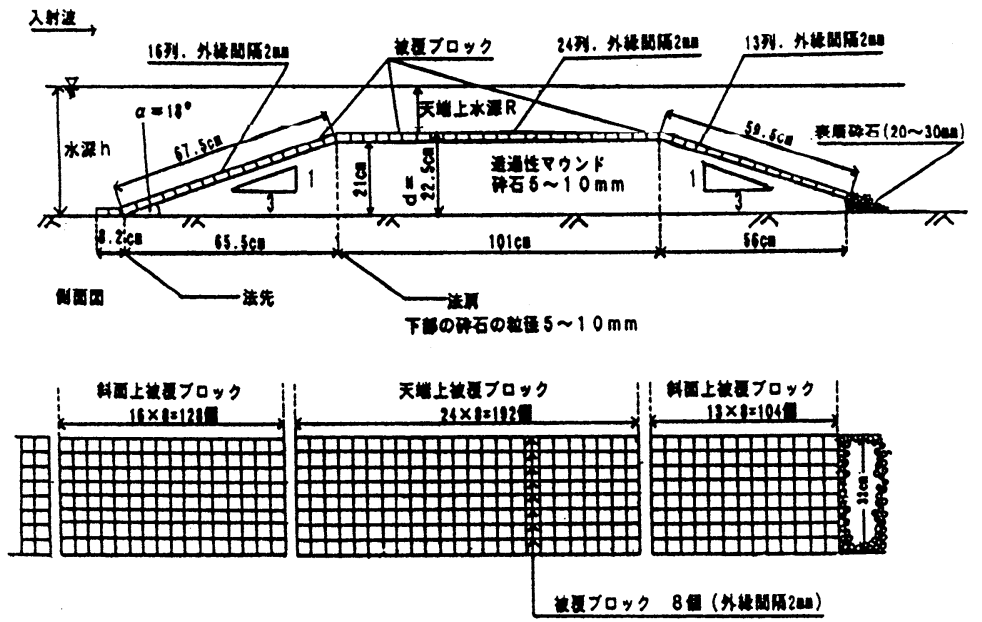

図-3 2 次元人エリーフの模型

幅が約1mと2 倍になっているが、その他の諸寸法および構造については、概略等しくしてある。もちろん、この ときの模型は、2 次元模型であるため、開口部はない。上記の 3 次元模型で、天端幅を 2 次元模型の $1 / 2$ に設定し たのは、被覆ブロックの総個数が足りなかったことが直接的な理由である。しかし、従来の 2 次元実験の結果に よると、ブロックの飛散や移動は、リーフの沖側前面の法肩やそれに近い天端上に集中しているため、2 次元の 移動実験においては、ある程度以上の天端幅があれば、ブロックの飛散や移動に及ぼす天端幅の影響はあまりを 大きくないものと推定され、このような設定とした。

2. 3 波変形の測定

人エリーフによる波浪制御効果を検討するため、リーフの反射波側と透過波側にそれぞれ容量式波高計を設置 した。特に 3 次元的なリーフの場合、リーフ背後で平面的な波変形が生じることが予測されるため、水槽の幅方 向に計 5 台の波高計を直線アレイで配置した。また、3 次元リーフ上の被覆ブロックの移動を考える際に重要と 考えられる、リーフ上の波高変動および位相速度の分布についても知るため、やはり計 5 台の直線アレイ波高計 群をリーフ上で波向き方向に移動させて、水面変動を測定した。

2. 4 被覆ブロックの移動状況

ブロックの移動は、経時変化によって徐々に生じるが、水槽端部よりの再反射波の影響も考えて、統一条件と して作用波数 100 波程度で打ち切って、そのときの観測結果で評価した。被覆ブロックの移動は、水槽の側面 から直接観察し、その様子を記録した。また、同時に水面上より、ビデオカメラによる撮影も行った。

2.5 実験条件

被覆ブロックの移動および透過波の測定は、同時に実施した。その とき用いた実験波の諸元（周期 $\mathrm{T}$, 波高 $\mathrm{H}$ ) を、天端上水深Rおよび 設置水深hと併せて表一 1 に示す。実験では、各設定周期の条件で、 被覆ブロックの飛散が見られるようになるまで、徐々に作用波高を増 加させた。一方、リーフ天端上の波高分布は、移動実験時にブロック の飛散がある場合およびない場合の代表例を選択して、それらの波条 件に対してのみ実施した。
表-1 実験波の条件

\begin{tabular}{|c|c|c|c|}
\hline $\begin{array}{c}\text { 設置水樑 } \\
\mathrm{h}(\mathrm{cm})\end{array}$ & $\begin{array}{c}\text { 天端上 } \\
\text { 水深 } \mathrm{R}(\mathrm{cm})\end{array}$ & $\begin{array}{c}\text { 周期 } \\
\mathrm{T}(\mathrm{sec})\end{array}$ & $\begin{array}{c}\text { 波高 } \\
\mathrm{H}(\mathrm{cm})\end{array}$ \\
\hline 25.5 & 2.0 & 1.23 & $4.1 \sim 9.8$ \\
\hline 25.5 & 2.0 & 1.40 & $4.1 \sim 9.1$ \\
\hline 25.5 & 2.0 & 1.56 & $4.2 \sim 8.3$ \\
\hline 25.5 & 2.0 & 1.75 & $4.0 \sim 8.8$ \\
\hline 28.0 & 4.5 & 1.23 & $5.6 \sim 11.4$ \\
\hline 28.0 & 4.5 & 1.40 & $5.6 \sim 12.3$ \\
\hline 28.0 & 4.5 & 1.58 & $6.4 \sim 11.2$ \\
\hline 28.0 & 4.5 & 1.75 & $6.9 \sim 10.2$ \\
\hline
\end{tabular}



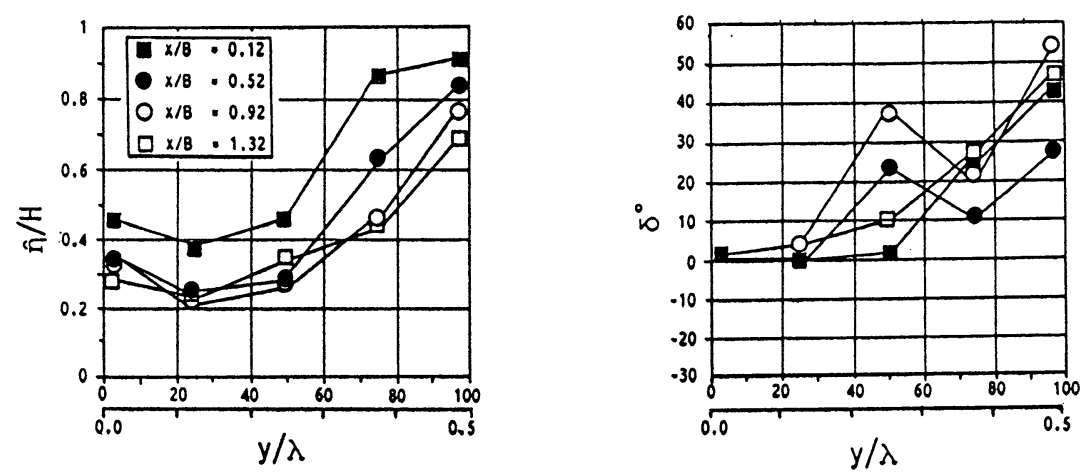

(a) $\mathrm{T}=1.23 \mathrm{sec}, \mathrm{H}=8.2 \mathrm{~cm}$
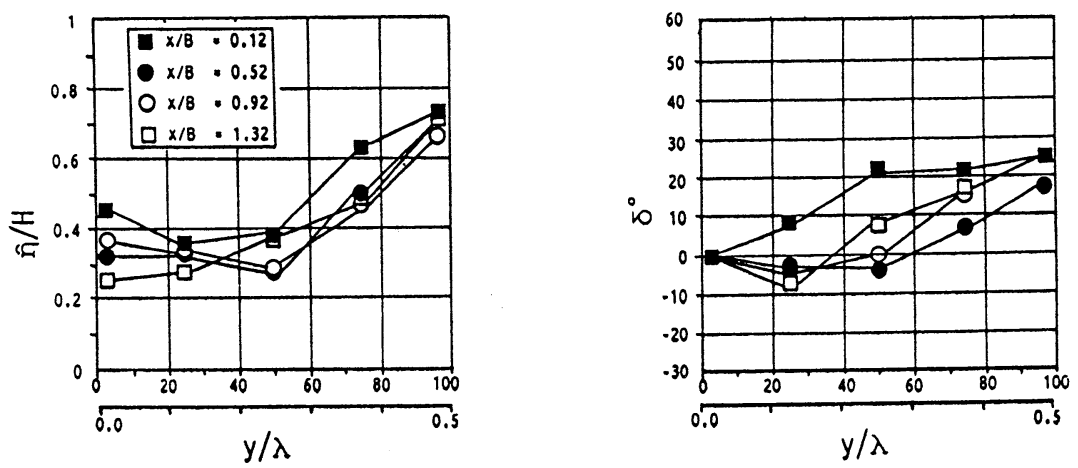

(b) $\mathrm{T}=1.41 \mathrm{sec}, \mathrm{H}=7.9 \mathrm{~cm}$

図ー4 天端上の波頂高商の分布とその出現位相 $8(\mathrm{R}=2.0 \mathrm{~cm})$
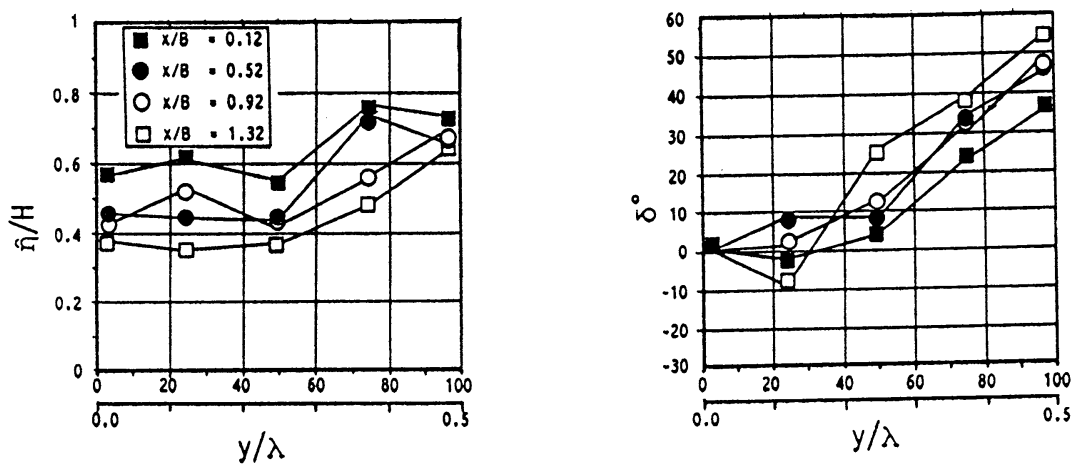

(a) $\mathrm{T}=1.24 \mathrm{sec}, \mathrm{H}=9.0 \mathrm{~cm}$
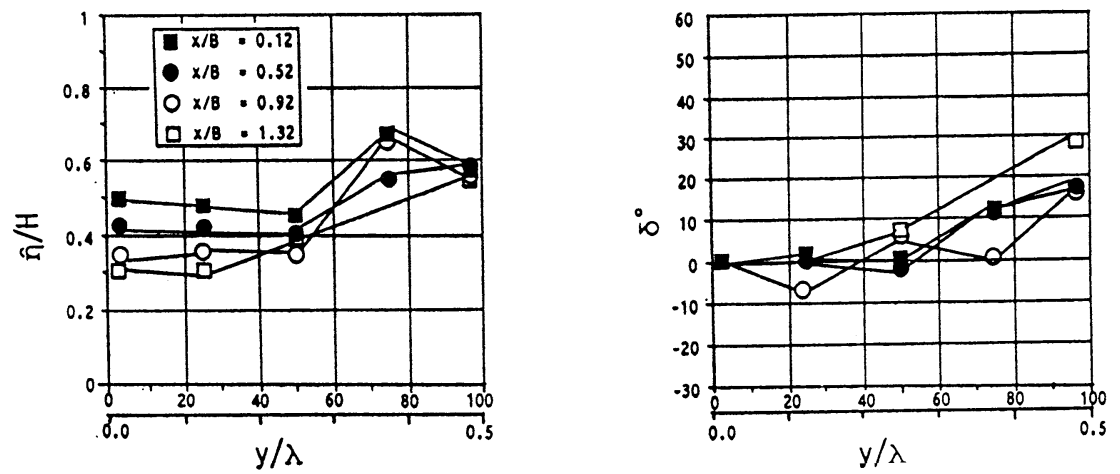

(b) $\mathrm{T}=1.38 \mathrm{sec}, \mathrm{H}=10.3 \mathrm{~cm}$

园一 5 天端上の波頂高令の分布とその出現位相 $\delta(R=4.5 \mathrm{~cm})$

3. 3 次元人エリーフ上の波頂高の分布特性

人エリーフによる浅水変形あるいは哗波の有無により、リーフ上に生起される波頂高の分布やその位相速度の 分布を知ることは、後述するリーフの耐波安定性を検討する上で重要になる。ここでは、代表的な波条件を対象 にして、天端上での波頂高クおよびその出現位相るの空間分布を検討してみた。なお、出現位相るは、リーフの波 向き直角方向における、天端の中心位置での位相を0度とした相対的な位相で表示した（位相遅れを正值と定 


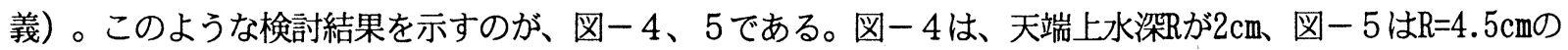
ときの結果に相当する。各図の左右には、それそれ波頂高 パラメータ（図中ではx/Bで表示、B:波向き方向天端幅）にしてプロットしてある。これらの図では横軸 $\mathrm{y}$ が配 列方向に、図の左端 $\mathrm{y}=100 \mathrm{~cm}(\mathrm{y} / \lambda=0.5)$ の位置が隣接する人エリーフの開口部の中心に相当し、開口部は横軸の 数值が56 100cmの区間にある。なお、これらの波条件下では、後述するように、いずれも被覆ブロックの飛散 が生じていたことを付記しておく。

これらの図より、周期や天端上水深に関係なく、ほぼ波頂高は開口部で最大值を示し、そのピークの出現位相 は開口部で最も遅れることなどが認められる。また、沖側天端端からの距離Xが増加して、波が天端上を進行す ると、特に天端上の波頂高は減少して波高が低減するのに対して、開口部での波頂高はあまり低下しないことな どの傾向が見られる。これは、天端上では波が強制砕波するのに対して、開口部ではほとんど砕波することなく 通過することによるものと考えられる。一方、波頂高の出現位相が、開口部で遅れるのは、やはり天端上では砕 波あるいは砤波後の波で、位相速度が増していることによるものと推定される。このような結果は、定形波を想 定した従来の波動理論による結果とは相反するもので、非常に興味深い。次に、周期の効果について検討してみ ると、周期が増大するにつれて、波頂高の配列方向への分布は緩やかになることや、位相遅れも小さくなるなど の傾向が見られる。また、天端上水深が深くなると、全体的に波頂高は平坦な分布を示すようになる。これは、 水深の増加により、砕波現象が緩和されることによるものと推定される。このような周期や天端上水深による変 動は、本質的には研波現象に関係しているものと推定される。

以上の検討結果から、3次元的な人エリーフ上では、天 端では強制砕波、開口部上では非研波になるなど、複雑な 波動場が形成されることや、波頂高は開口部で最大になり、 その位相速度は天端上に比較して小さくなることなどが判 明した。

\section{4.被覆ブロックの移動特性}

本実験の範囲内で観測されたブロックの移動状況は、2 次元および 3 次元模型共に、作用波高が増大すると、まず 最初に滑動し、ブロック前後間に隙間が生じ始める。さら に波高が増大すると、その隙間は拡大し、遮蔽効果が減少 するため、最終的に鉛直回転して飛散する例が大多数で あった。ただし、3 次元模型では、特に開口側の天端端で よく見られた例として、平面的に回転滑動して、隙間が拡 大して飛散する例がよく観測された。

\section{13 次元模型での移動状況}

図一6、7は、3次元実験で採用した全ての波条件を対 象にして、飛散したブロックの分布状況を天端上水深別に 示す。罒中で平面軸はブロックの平面配列位置を、鉛直軸 は飛散回数を表す。この飛散回数は、各波条件での波列に 対して飛散が見られれば1とし、見られないときには0とし て集計して得られた值である。これらの図より、ブロック が飛散する位置は、主に天端上でしかも開口部に近い所で あることや天端上水深が深くなると天端の周辺端部に拡が ることなどがわかる。そして、ブロックの飛散例は、配列 位置が開口部から遠ざかるにつれて急激に減少し、この傾 向はリーフの中央部付近でより顕著になっている。

このように、3次元模型でブロックの飛散が開口部付近 の天端に集中する理由としては、上記の 3 . で示したよう

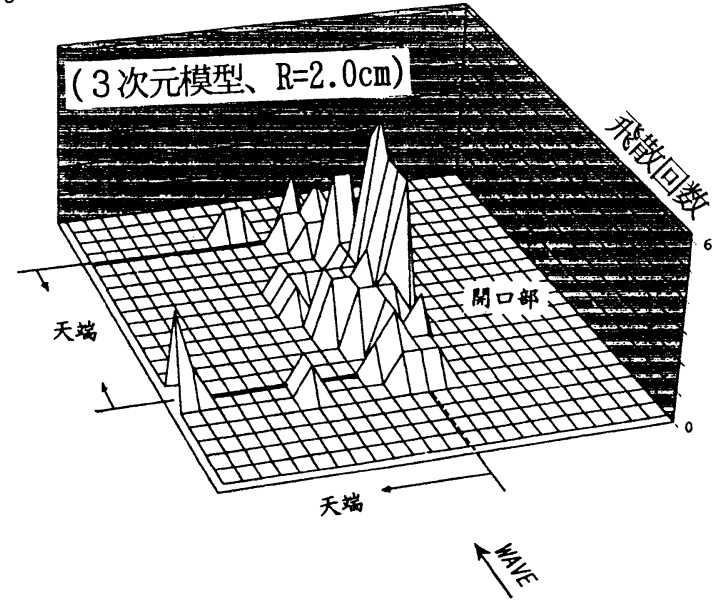

図-6 飛散ブロックの分布状況

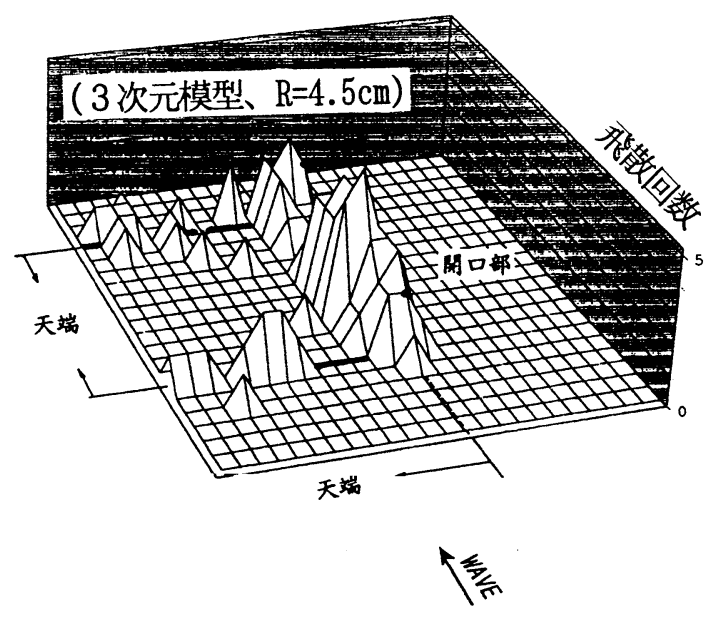

図-7 飛散ブロックの分布状況 に、開口部付近では砕波することなく高波高の波が通過し、しかも天端中央部付近で砕波した後の段波状の水塊 が開口部に流れやすいためと考えられる。これは、開口部付近に位置するプロックでは、最初に平面的に回転滑 動を始め、この回転滑動によりできた隙間が被災の直接のきっかけとなる例が多く観測された事実とも一致する。

建設省での一連の研究成果を基づき作成された人エリーフの設計の手引き $\left.{ }^{7}\right)$ によれば、3 次元リーフでの開 口部側面の所用重量は、沖側法面のそれに比較して同程度かそれより低減できるとされている。しかしながら、 本実験での結果によれは、このような設計指針は十分なものでなく、むしろ開口部付近では所要重量を増すこと 


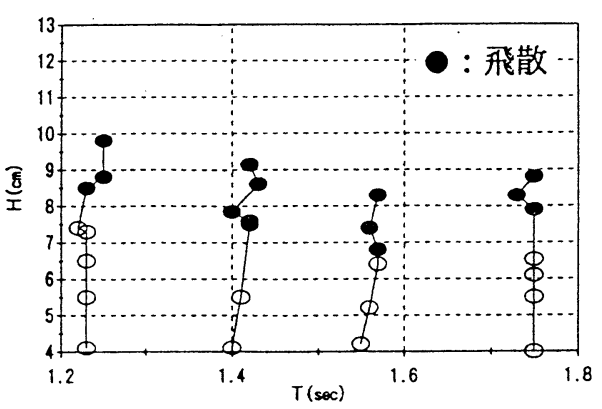

(a) $\mathrm{h}=25.0 \mathrm{~cm}, \mathrm{R}=2.0 \mathrm{~cm}$

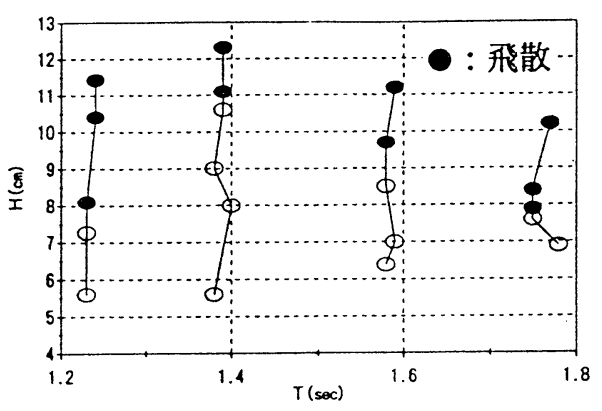

(b) $\mathrm{h}=28.0 \mathrm{~cm}, \mathrm{R}=4.5 \mathrm{~cm}$

図一-8 3 次元模型で飛散の見られた波条件（黒塗り=飛散）

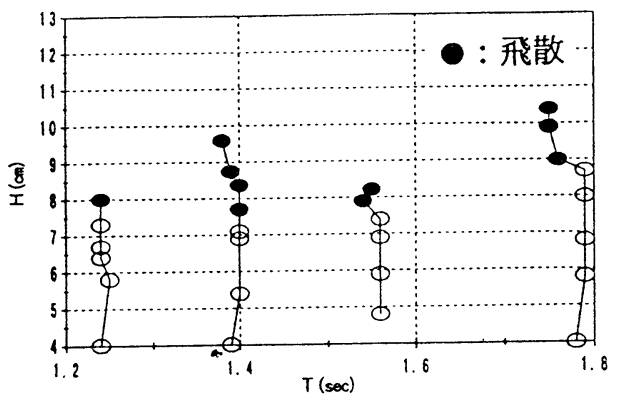

(a) $\mathrm{h}=24.6 \mathrm{~cm}, \mathrm{R}=2.1 \mathrm{~cm}$

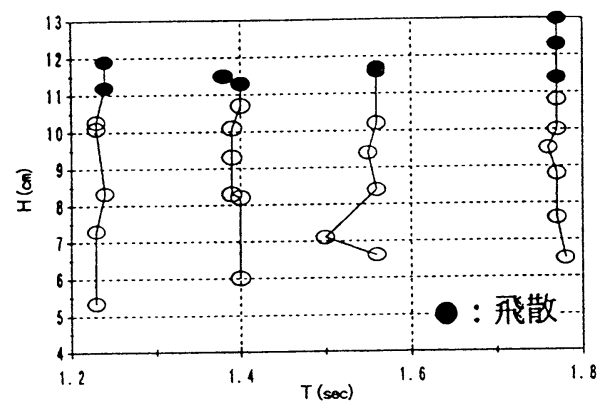

(b) $\mathrm{h}=27.0 \mathrm{~cm}, \mathrm{R}=4.5 \mathrm{~cm}$

図一-10 2 次元模型で飛散の見られた波条件（黒塗り=飛散）

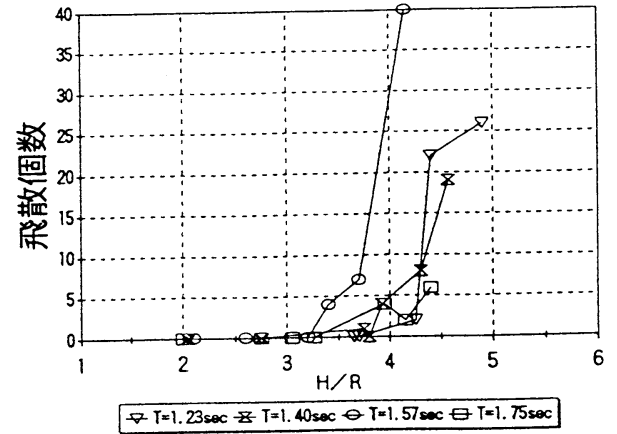

(a) $\mathrm{h}=25.5 \mathrm{~cm}, \mathrm{R}=\mathbf{2 . 0 \mathrm { cm }}$

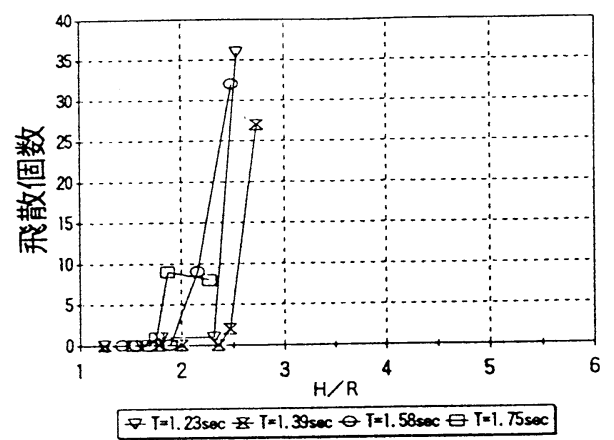

(b) $h=28.0 \mathrm{~cm}, \mathrm{R}=4.5 \mathrm{~cm}$

図-9 相対波高と飛散個数（3 次元模型）

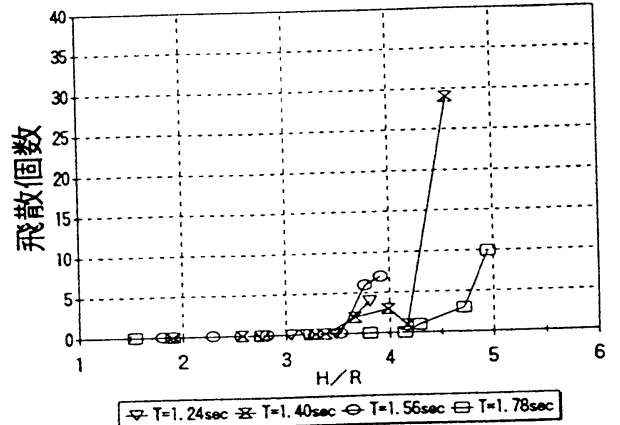

(a) $h=24.6 \mathrm{~cm}, R=2.1 \mathrm{~cm}$

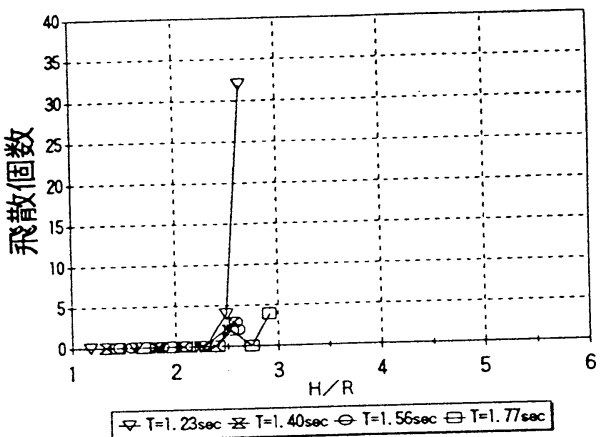

(b) $b=27.0 \mathrm{~cm}, \mathrm{R}=4.5 \mathrm{~cm}$

図-1 1 相対波高と飛散個数（2 次元模型）

が必要になるものと言えよう。一方、天端上水深を深くすると、天端の後端部（岸側）での飛散例が見られるよ うになる。これは、天端上水深が深くなると、砕波点が前端法面上より天端上へと移動し、砕波の突入点が天端 の後端部に一致するようになり、被覆ブロックが滑落しやくなるためである。

次に、図一8は、各作用波高および周期の条件下での移動状況を各天端上水深別に示すもので、図中ではブ ロックの飛散が見られたときの波条件に対するマークを黒く塗りつぶしてある。この図より、天端上水深が深く 
なると、飛散の見られる限界波高は高くなることや、この傾向は本実験の範囲内では中程度の周期帯で顕著であ ることなどがわかる。これは、 Rが大きくなると、砕波に伴う天端上表面での水平流速が低下することが直接的 な原因と推定される。また、この移動限界波高の周期による変化は、天端上水深の深い場合に大きくなっている。

図-9は、図-8では評価できないブロックの飛散個数と作用波高との関係を示すもので、図中では天端上水 深との相対波高の関係でプロットしてある。この図より、ブロックの飛散個数は、最も長周期の波では $5-10$ 個程度とあまり多くないのに対して、短・中周期の波では、作用波高の増大により20〜30個と壊滅的な打撃を与 えることがわかる。そして、各天端上水深に対して、壊滅的な被害を与える波高は、 $\mathrm{T}=1.4 \mathrm{sec} 、 1.6 \mathrm{sec} の 中$ 程度 の周期帯で最も低くなっていることが認められる。このような周期に伴う限界波高の変化は、作用波の周期によ りリーフ上での砕波点や砕波の突っ込み点の位置が変化することが主要な原因と推察される。

\section{2 2 次元実験による結果との比較}

図-1 0、1 1は、2 次元実験による結果を示すもので、前出の 3 次元実験の図-8、9 結果に対応してい る。まず、飛散の見られる限界波高を示す図 -10 と 3 次元のそれ図- 8 とを比較してみると、 $\mathrm{R}=2 \mathrm{~cm}$ と浅い場 合には、飛散が始まる限界波高は約 $8 \mathrm{~cm}$ 程度とほぼ等しいものの、 $\mathrm{R}=4.5 \mathrm{~cm}$ 場合、多少のばらつきはあるが、 2 次元模型の方が3cm程度高くなっている。特にこの傾向は、実験範囲内で、短周期と長周期の波で顕著に現れて いる。また、飛散個数との関係を示す図-1 1 と対応する 3 次元のそれ図 -9 を比較すると、同様の傾向が認め られ、壊滅的な被害が生じる限界波高は、全体的に 3 次元模型の方が低くなっている。これは、3 次元模型では 図一6、7に見られるように開口部付近での被覆ブロックの被害状況が顕著になるためで、直接的には、3．で 実験的に示したように開口部に高波高が出現することによる。そして、このような 2 次元と 3 次元の移動特性の 相違は、リーフ天端まわりの波変形の違いによるものと結論される。

以上の検討より、人エリーフ上の被覆ブロックの耐波安定性に及ぼす開口部の影響は無視できないことや、断 面 2 次元的な結果で代用すると危険な設計となることなどが判明した。また、注意すべきことは、2 次元模型に よる結果で指摘されているようなリーフ前面の法肩及びその近傍の天端上でのブロックの移動は、3 次元模型に おいても見られるが、ブロックの移動が顕著なのは特に開口部側であることで、3 次元模型の移動状況と 2 次元 模型のそれとは異なることを強調しておきたい。

5. 結 語

（1）開口部を有する 3 次元的な人エリーフでは、リーフの天端上では強制砕波、開口部では非砕波になるなど 複雑な波動場が形成される。そして、開口部には、天端上での砕波後の流体塊が横から流れ込みやすく、しかも 位相速度は天端上の方が速いため、絬果的に波頂高さは開口部の方が天端上よりも高くなる。

（2）３次元的な人工リーフ上の被覆ブロックの移動状況は、2 次元の場合と同様に時間的に移動が進行するか 否かで大別できるが、その移動状況は、開口部付近に位置するブロックで平面的に回転滑動した後に鉛直回転し て飛散する例が多いなど、2 次元のそれとは異なる。

（3）３次元的な人エリーフ上の被覆ブロックの移動や飛散は、2 次元の場合と異なり、開口部付近に位置する ブロックで著しく、2 次元の場合より低い波高で生じる。これは上記した天端上の波高分布や位相速度の特性と 密接に関係している。そして、被覆材の安定重量の算定には、開口部の効果など 3 次元的な影響を是非考慮する 必要がある。

\section{参考文献}

1)Hudson,R.Y.: Laboratory investigation of rubble mound breakwaters, Proc.ASCE, Vol.85, No. WW3, PP.93-1 21,1959 .

2) Brebner, A. and D. Donnelly: Laboratory study of rubble foundation for vertical breakwaters, Proc. 8th Conf. on Coastal Eng., pp.408-429,1962.

3 ) 宇多高明・小俣篤・横山揚久: 人エリーフの被覆材料の所要重量算定法, 海岸工学論文集, 第 36 巻, pp.648-652, 1989 .

4 ) 宇多高明・小俣篤・斎藤友伸：人エリーフ被覆材の所要重量算定法, 土木研究所資料, 第2893号, 1990 .

5 ) 水谷法美 - 岩田好一郎・ T . M . R u f i n - 倉田克彦：幅広潜堤上の被覆材に作用する波力の特性と移動限 界に関する実験的研究、海岸工学論文集、第38巻、pp.591-595, 1991 .

6) 中村孝幸・大塚明人・小野塚孝・森貴人：人エリーフ上の被覆ブロックに作用する波力の特性について、海洋 開発論文集、第8巻、pp.69-74,1992.

7) 建設省河川局海岸課：人エリーフの設計の手引き、（社）全国海岸協会、p.94、1992. 